\title{
Anti-thrombotic agents derived from snake venom proteins
}

\author{
Tur-Fu Huang ${ }^{*}$, Chun-Chieh Hsu and Yu-Ju Kuo \\ From The 9th Congress of the Asian-Pacific Society on Thrombosis and Hemostasis \\ Taipei, Taiwan. 6-9 October 2016
}

\begin{abstract}
Snake venoms affect blood coagulation and platelet function in a complex manner. However, two classes of venom proteins, snaclecs and disintegrins have been shown to specifically target receptors including GPIb, a2 $\beta 1, G P V I$, CLEC-2 and integrins allb $\beta 3$, av $\beta 3, a 5 \beta 1$ expressed on platelets, endothelial cells, phagocytes, tumor cells, thus affecting cell-matrices and cell-cell interactions. Here, we focus on disintegrins, a class of low molecular mass Arg-Gly-Asp(RGD)/Lys-Gly-Asp(KGD)-containing, cysteine-rich polypeptide derived from various viper snake venoms. This review describes the potential applications of disintegrins in field of integrin-related diseases, especially arterial thrombosis, angiogenesis, tumor progression and septic inflammation. In addition, a novel RGD-containing disintegrin TMV-7 is being developed as a safer antithrombotic agent with minimal side effects, such as thrombocytopenia and bleeding.
\end{abstract}

Keywords: Snake venom proteins, Disintegrins, Antithrombotic agent, Arterial thrombosis, Angiogenesis, Septic inflammation

Abbreviations: ADP, Adenosine diphosphate; ECM, Extracellular matrix; KGD, Lys-Gly-Asp; LIBs, Ligand-induced binding sites; LPS, Lipopolysaccharide; mAb, Monoclonal antibody; PCI, Percutaneous coronary intervention; PEG, Polyethylene glycol; PLA2, Phospholipase A2; PTCA, Percutaneous transluminal coronary angioplasty; RGD, Arg-Gly-Asp; SVMP, Snake venom metalloproteinase; TLR, Toll-like receptor; VWF, von Willebrand factor

\section{Background}

Viperidae snake venoms profoundly affect blood coagulation and platelet function. Ouyang et al. [1] classified them into procoagulants, including factor $\mathrm{X}$ activator, prothrombin activator, thrombin-like enzymes and platelet aggregation inducer, and coagulation inhibitors, including fibrinogenolytic enzymes, prothrombin activation inhibitor, Factor X inhibitors, and platelet aggregation inhibitors. This review will focus on the active components that inhibit platelet function. Regarding platelet aggregation inhibitors, many venom components including ADPase, snake venom metalloproteinase (SVMP), phospholipase A2, GPIb and IX binding proteins (i.e. snaclec) and disintegrins have been reported to suppress platelet aggregation in vitro. However, snaclecs and disintegrins affect in vivo

\footnotetext{
* Correspondence: turfu@ntu.edu.tw

Institute of Pharmacology, College of Medicine, National Taiwan University, No.1, Sec. 1, Jen-Ai Rd, Taipei, Taiwan
}

(c) 2016 The Author(s). Open Access This article is distributed under the terms of the Creative Commons Attribution 4.0 International License (http://creativecommons.org/licenses/by/4.0/), which permits unrestricted use, distribution, and reproduction in any medium, provided you give appropriate credit to the original author(s) and the source, provide a link to the Creative Commons license, and indicate if changes were made. The Creative Commons Public Domain Dedication waiver (http://creativecommons.org/publicdomain/zero/1.0/) applies to the data made available in this article, unless otherwise stated. 
$\alpha 2 \beta 1 /$ GPVI, $\alpha 5 \beta 1, \alpha 6 \beta 1$ or $\alpha \operatorname{IIb} \beta 3)$. Nowadays, $\alpha 2 \beta 1 /$ GPVI are known to mediate collagen adhesion/activation of platelets, whereas $\alpha \mathrm{IIb} \beta 3$ mediates the adhesion of fibrinogen, and the subsequent platelet-platelet aggregation, a common final step of platelet aggregation shared all stimulating agonists $[4,5]$. Generally, the activation of platelets consists of many signal transduction pathways including PLA2/PLC activation and the rise of cytosolic free $\mathrm{Ca}^{2+}$ after the ligation of agonist with its receptor, leading to shape change, release reaction of ADP and serotonin as well as thromboxane A2 formation, enhancement of procoagulation activity, and finally the activation of $\alpha \operatorname{IIb} \beta 3$. The binding of plasma fibrinogen to the activated $\alpha \operatorname{IIb} \beta 3$ bridges adjacent platelets and lead to platelet aggregation which is reinforced by the subsequent fibrin formation forming a hemostatic plug. However, pathological thrombi may be formed due to chronic endothelial injury in atherosclerotic patients [6].

\section{Disintegrins as anti-thrombotic agents}

Trigramin, a non-enzymatic small molecular weight polypeptide, was first discovered in 1987 [7]. Our earlier studies showed that disintegrins derived from T. gramineus, Agkistrodon halys, and Agkistrodon rhodostoma [8-10] inhibited platelet aggregation elicited by various aggregation agonists including ADP, epinephrine, sodium arachidonate, collagen and $\mathrm{Ca}^{2+}$ ionophone A23187 with similar IC50 concentrations. They neither affect shape change nor the cAMP level. Further studies showed that trigramin and echistatin purified from $T$. gramineus and Echis carinatus, inhibited fibrinogen binding to ADP-stimulated platelets [7, 11]. ${ }^{125}$ I-trigramin showed less than $5 \%$ binding to ADP-stimulated platelets in Glanzmann's thrombasthenia patients (a genetic disease with $\alpha$ IIb $\beta 3$-defect) compared to normal platelets, suggesting that $\alpha \operatorname{IIb} \beta 3$ is the target of trigramin. In addition, 7E3 mAb raised against $\alpha \operatorname{IIb} \beta 3$ and RGDS inhibited ${ }^{125}$ I-trigramin binding. Subsequent sequencing of trigramin showed that it is a RGD-containing single polypeptide with 72 amino acid residues and six disulfide bonds. Reduced trigramin lost its inhibitory activity for platelet aggregation and binding capacity to platelets, indicating that the biological activity of trigramin depends upon the presence of the RGD sequence and its steric structure maintained by disulfide bridges $[7,12]$. Upon intravenous administration, trigramin prolonged the bleeding time of severed mesentery arteries, further supporting its in vivo antithrombotic activity [13]. Later, other disintegrins, such as kistrin and applagin were also shown to prevent experimental thrombosis in dogs $[14,15]$. Since then, many pharmaceutical companies have developed potential antithrombotic agents based on the structure of these disintegrins. Among these disintegrins, barbourin, a KGD-containing polypeptide, showed a higher specificity toward platelet $\alpha I I \beta 3$ than to endothelial $\alpha v \beta 3$ [16]. Thus, eptifibatide (Integrillin), a cyclic KGD-peptide, has been successfully developed as an $\alpha \operatorname{IIb} \beta 3$ antagonist, used clinically for prevention of restenosis during percutaneous transluminal coronary angioplasty (PTCA) [17]. Tirofiban is also designed to mimic the RGD-loop structure of the disintegrin, echistatin [18]. In contrast to the first antiaggregation agent, the chimeric monoclonal c7E3Fab (Abciximab, Reopro) a mAb raised against $\alpha \operatorname{IIb} \beta 3$ [19], tirofiban and eptifibatide are small-mass $\alpha \operatorname{IIb} \beta 3$ antagonists derived from snake venom disintegrins. Vipegitide, a folded KTS-containing peptidomimetic molecule, inhibited the adhesion of $\alpha 1 / \alpha 2$ integrin toward collagen, and ADP and collagen-I induced platelet aggregation in PRP and whole human blood [20], providing strategy for developing $\alpha 2 \beta 1$ antagonists as antiplatelet agents.

\section{Disintegrins as an anti-tumor and anti-angiogenesis agents}

Integrin $\alpha v \beta 3$ modulates adhesion, migration and proliferation of endothelial cells, smooth muscles, fibroblasts and transformed cells, and thus plays crucial roles in angiogenesis, restenosis, tumor cell migration and atherosclerosis [21]. It has been reported that disintegrins inhibit adhesion of tumor cells and endothelial cells to extracellular matrix (ECM) through $\alpha v \beta 3$ and $\alpha 5 \beta 1$. Trigramin inhibited human melanoma cells adhesion and spreading on fibronectin and fibrinogen [22], and trifavin inhibited lung colonization of B16F10 melanoma cells in an experimental model [23].

We previously reported that some disintegrins (accutin, rhodostomin) dose-dependently inhibited the adhesion of endothelial cells to ECM, cell proliferation, matrigelinduced capillary tube formation, and neovascularization in a chick chorioallantoic membrane (CAM) model, mainly through $\alpha v \beta 3$ blockade [24]. Accutin is the first disintegrin reported to induce apoptosis of HUVECs [25]. Rhodostomin caused a higher percentage of cells at G2/M phase, the cleavage of $\beta$-catenin, and poly (ADP-ribose) polymerase during apoptosis [26]. Contortrostatin, a dimeric disintegrin that binds to $\alpha v \beta 3$, $\alpha v \beta 5$ and/or $\alpha 5 \beta 1$, was shown to inhibit the adhesion and invasion of tumor cells and endothelial cells in vitro. In an orthotopic xenograft model in nude mice, contortorstatin displayed good anti-tumor and antiangiogenic potential against a breast cancer cell line (MDA-MB-435) [27]. Vimocin and Vidapin, two synthetic peptides derived form KTS-containing disintegrins obtustatin and viperistatin, were shown to inhibit angiogenesis induced by VEGF and glioma in CAM assay, suggesting that they may serve as dual $\alpha 1 \beta 1 / \alpha 2 \beta 1$ integrin antagonists in anti-angiogenesis and cancer therapy [28]. Cilengitide, an RGD-containing pentapeptide and other $\alpha v$ integrin inhibitors have entered phase 
II/III clinical study as monotherapy for different tumor types. However, Cilengitide did not alter the pattern of glioblastoma progression [29], and in a phase III clinical trial, the addition of Cilengitide to standard care did not improve overall survival in patients with newly diagnosed glioblastoma [30]. There are still some on-going phase I-II clinical trials in combinative therapy for glioblastoma and non-small-cell lung cancer [31,32].

\section{Disintegrins as anti-inflammatory agents}

The innate immune system is the first line of defense against microbial pathogens, protecting the host from infection. In humans, Toll-like receptors (TLRs) specifically recognize different microbial patterns to initiate signaling pathways leading to inflammation [33]. TLR4 recognizes lipopolysaccharide (LPS) -containing Gram negative bacteria while TLR2 recognizes peptidoglycan of Gram positive bacteria [34]. The $\beta 2$ and $\beta 3$ integrins regulate leukocyte trafficking and function. Vitronectin and $\alpha v \beta 3$ have roles in initiating TLR2 responses to bacterial lipopeptide [35]. Our recent studies showed that the disintegrin rhodostomin $(\mathrm{Rn})$ possesses anti-inflammatory activity mainly through blocking $\alpha v \beta 3$-induced NFkB and MAPK pathways, and MyD88-dependent TLRs (including TLR2 and 4) in the production of cytokines in phagocytes. Thus, Rn suppresses cytokine release, inhibits cell adhesion and migration in vitro and even attenuates the acute inflammatory activity in mice caused by bacterial infections $[36,37]$. The activation of coagulation leading to microvascular thrombi causes multiple organ failure and correlates with mortality in severe sepsis [34]. Rn was also shown to increase significantly the survival rate of septic mice [36, 37]. The antiplatelet activity of $\mathrm{Rn}$ through $\alpha \mathrm{IIb} \beta 3$ blockade may be partially responsible for its capacity to reduce thrombi formation. The potential application of rhodostomin as an inhibitor of TLR-2 and TLR-4 activation provides a promising lead for drug development in infectious diseases induced by complicated microbial patterns.

\section{Novel allb $\beta 3$ antagonists derived from disintegrins}

Although clinically available $\alpha \operatorname{Ilb} \beta 3$ antagonists are highly efficacious antithrombotics, their uses are currently limited to percutaneous coronary intervention (PCI) due to adverse reactions of thrombocytopenia and bleeding. Increased bleeding risk prevents this class of $\alpha \operatorname{IIb} \beta 3$ antagonists from being used at higher doses and in patients at risk of bleeding [38]. It has been recognized that binding of RGD-mimetic drugs including tirofiban and eptifibatide to the RGD recognition site of $\alpha I I b \beta 3$ induces conformational changes and exposure of $\alpha \operatorname{IIb} \beta 3$ neoepitopes (called ligand-induced binding sites, LIBs) which are recognized by several murine monoclonal antibodies [39]. As a consequence, patients with preformed antibodies against LIBs may engage the integrin $\beta 3$ subunit such that FcyRII and its downstream signaling pathways become activated, resulting in platelet clearance from circulation and concomitant thrombocytopenia [40, 41]. Thus, it is crucial to develop novel $\alpha \operatorname{IIb} \beta 3$ antagonists that do not cause thrombocytopenia or bleeding. Recently RUC-1,2 and 4 compounds have been shown to be efficacious $\alpha \operatorname{IIb} \beta 3$ antagonist with minimal effect in altering the $\alpha \operatorname{IIb} \beta 3$ conformation $[42,43]$. On the other hand, a membrane permeable compound, mp6, was shown to inhibit the outside-in signaling without affecting the fibrinogen$\alpha \operatorname{IIb} \beta 3$ ligation [44]. In our laboratory, we found a unique RGD-containing disintegrin, TMV-7, purified from T. macrosquamatus venom, which like RUC-2, had a minimal priming effect in induction of fibrinogen-binding or PAC-1 binding, reflecting that TMV-7 induces little exposure of LIBs (unpublished data). It binds preferably to $\alpha \mathrm{IIb}$, a binding epitope different from those of $\mathrm{mAb} 7 \mathrm{E} 3$, tirofiban, eptifibatide and most RGD-containing disintegrins including dimeric disintegrin, and short- and medium-size disintegrins. TMV-7 has also been shown to be an efficacious antithrombotic agent in $\mathrm{FeCl}_{3}$-induced carotid artery injury, and irradiation-induced mesenteric thrombosis models. At effective doses, TMV-7 did not significantly prolong the bleeding time. Its unique mechanism of action may be related to inhibiting outside-in signaling without affecting talin-mediated inside-out signaling and clot retraction. Recent studies show that Go13 and talin play critical roles in thrombin-induced integrin bidirectional signaling and bind to mutually exclusive but distinct sites within integrin $\beta 3$ cytoplasmic domain in opposing waves, suggesting that targeting outside-in signaling may prevent thrombosis without affecting physiological hemostasis [45-47]. Therefore, the elucidation of the structure-activity relationship between TMV-7 and $\alpha \operatorname{IIb} \beta 3$ on a molecular level may provide clues for drug development of an ideal antithrombotic RGD-mimetic with a better safety profile.

\section{Translational medicine derived from disintegrins}

Over the last three decades, extensive researches on RGD/KGD-containing disintegrins focused on their interaction with platelet $\alpha \operatorname{IIb} \beta 3$ and endothelial or tumor $\alpha v \beta 3$, resulting in the successful development of the efficacious $\alpha \operatorname{IIb} \beta 3$ antithrombotic agents such as tirofiban and eptifibatide. However, the efforts for application of $\alpha v \beta 3$-specific RGD-mimetics in tumor therapy are still going-on. The possible potential use of $\alpha v \beta 3$ disintegrin in septic inflammation is worthy of further investigation. However, the possible antigenicity and brief half-life of intact disintegrins in circulation limit their direct ultilization as therapeutic agents although their molecular masses are usually around $4000 \sim 7000$ daltons. A alternative strategy 
in developing these disintegrins may be approached by PEGylation or conjugation with human serum albumin to minimize antigenicity or prolong their half-lives. A PEGylated $\alpha \operatorname{IIb} \beta 3$ disintegrin (PEGylated rhodostomin) has been reported to have an improved antithrombotic activity [48]. PEGylated rhodostomin (PRn) has higher antithrombotic potency and a longer half-life in vivo compared with native rhodostomin. In addition, PRn shows a better safety profile at an effective dose in vivo. Therefore, PEGylation may be one ideal option in modifying disintegrin derivatives to produce a safe therapeutic agent.

\section{Conclusions}

The discovery of the naturally occurring disintegrins has inspired much research into the molecular interaction of RGD/KGD disintegrins with integrin $\alpha \mathrm{IIb} \beta 3, \alpha v \beta 3$ and other integrins, leading to drug development of potential agents in the fields of arterial thrombosis, angiogenesis, tumor metastasis, inflammation and other integrinrelated diseases. With the aid of advanced molecular biology techniques and the elucidation of physiological and pathological roles of integrins, these disintegrins and their mutants, targeting the binding site of the specific integrin would be helpful for the further dissection of their efficacy and adverse reactions mechanisms.

$\mathrm{X}$-ray crystallography, ligand-receptor docking and bioinformatics regarding the binding ligands (disintegrin and mutants) toward integrins, and their atomic interactions should accelerate the discovery of novel therapeutic agents, especially the small-mass RGD-mimetics derived from the naturally-occurring disintegrins.

\section{Acknowledgements}

We acknowledge fundings from Ministry of Science and Technology of Taiwan MOST103-2321-B002-089 and MOST 104-2321-B-002-035.

\section{Declaration}

Publication fees for this article have been funded by APSTH 2016. This article has been published as part of Thrombosis Journal Volume 14 Supplement 1, 2016. The full contents of the supplement are available at https://thrombosisjournal.biomedcentral.com/articles/supplements/volume14-supplement-1

Availability of data and material

Not applicable.

\section{Authors' contributions \\ Review concept and design: TFH Acquisition of data: $\mathrm{CCH}$, YJK Analysis and interpretation of data: TFH, CCH, YJK Drafting of the manuscript: TFH Study supervision: TFH had full access to all the data in the review and take responsibility for the integrity of the manuscript. All authors read and approved the final manuscript.}

\section{Competing interests}

The authors declare that they have no competing interests.
Ethics approval and consent to participate

Not applicable.

Published: 4 October 2016

\section{References}

1. Teng CM, Huang TF. Snake venom constituents that affect platelet function. Platelets. 1991;2:77-87.

2. Clemetson KJ. Snaclecs (snake C-type lectins) that inhibit or activate platelets by binding to receptors. Toxicon. 2010;56:1236-46.

3. Hynes RO. Integrins - versatility, modulation, and signaling in cell-adhesion. Cell. 1992;69:11-25.

4. Ginsberg MH, Loftus JC, Plow EF. Cytoadhesins, integrins, and platelets. Thromb Haemost. 1988;59:1-6.

5. Watson SP, Auger JM, MCCarty OJT, Pearce AC. GPVI and integrin alpha II beta 3 signaling in platelets. J Thromb Haemost. 2005;3:1752-62.

6. Coller BS. Platelets and thrombolytic therapy. N Engl J Med. 1990;322:33-42.

7. Huang TF, Holt JC, Lukasiewicz H, Niewiarowski S. Trigramin - a lowmolecular-weight peptide inhibiting fibrinogen interaction with platelet receptors expressed on glycoprotein-llb-Illa complex. J Biol Chem. 1987; 262:16157-63.

8. Huang TF, Ouyang C. Action mechanism of the potent platelet-aggregation inhibitor from Trimeresurus gramineus snake venom. Thromb Res. 1984;33: 125-38.

9. Huang TF, Liu CZ, Ouyang CH, Teng CM. Halysin, an antiplatelet Arg-GlyAsp-containing snake venom peptide, as fibrinogen receptor antagonist. Biochem Pharmacol. 1991;42:1209-19.

10. Huang TF, Wu YJ, Ouyang C. Characterization of a potent platelet aggregation inhibitor from Agkistrodon rhodostoma snake venom. Biochim Biophys Acta. 1987;925:248-57.

11. Gan ZR, Gould RJ, Jacobs JW, Friedman PA, Polokoff MA. Echistatin. A potent platelet aggregation inhibitor from the venom of the viper, Echis carinatus. J Biol Chem. 1988;263:19827-32.

12. Huang TF, Holt JC, Kirby EP, Niewiarowski S. Trigramin: primary structure and its inhibition of von Willebrand factor binding to glycoprotein IIb/IIla complex on human platelets. Biochemistry. 1989;28:661-6.

13. Cook JJ, Huang TF, Rucinski B, Strzyzewski M, Tuma RF, Williams JA, et al. Inhibition of platelet hemostatic plug formation by trigramin, a novel RGD-peptide. Am J Physiol. 1989;256:H1038-43.

14. Yasuda T, Gold HK, Leinbach RC, Yaoita H, Fallon JT, Guerrero L, et al. Kistrin, a polypeptide platelet GPIIb/IIla receptor antagonist, enhances and sustains coronary arterial thrombolysis with recombinant tissue-type plasminogen activator in a canine preparation. Circulation. 1991;83:1038-47.

15. Rote WE, Mu DX, Roncinske RA, Frelinger 3rd AL, Lucchesi BR. Prevention of experimental carotid artery thrombosis by applaggin. J Pharmacol Exp Ther. 1993;267:809-14.

16. Scarborough RM, Rose JW, Hsu MA, Phillips DR, Fried VA, Campbell AM, et al. Barbourin. A GPIIlb-llla-specific integrin antagonist from the venom of Sistrurus m. barbouri. J Biol Chem. 1991;266:9359-62.

17. Scarborough RM, Naughton MA, Teng W, Rose JW, Phillips DR, Nannizzi L, et al. Design of potent and specific integrin antagonists. Peptide antagonists with high specificity for glycoprotein Ilb-Illa. J Biol Chem. 1993: 268:1066-73.

18. Gould RJ, Polokoff MA, Friedman PA, Huang TF, Holt JC, Cook JJ, et al. Disintegrins: a family of integrin inhibitory proteins from viper venoms. Proc Soc Exp Biol Med. 1990;195:168-71.

19. Califf RM, Shadoff N, Valett N, Bates E, Galeana A, Knopf W, et al. Use of a monoclonal antibody directed against the platelet glycoprotein Ilb/lla receptor in high-risk coronary angioplasty. N Engl J Med. 1994;330:956-61.

20. Momic T, Katzhendler J, Shai E, Noy E, Senderowitz H, Eble JA, et al. Vipegitide: a folded peptidomimetic partial antagonist of alpha2beta1 integrin with antiplatelet aggregation activity. Drug Des Devel Ther. 2015:9:291-304

21. Jia $L G$, Wang XM, Shannon JD, Bjarnason JB, Fox JW. Function of disintegrin-like/cysteine-rich domains of atrolysin A. Inhibition of platelet aggregation by recombinant protein and peptide antagonists. J Biol Chem. 1997:272:13094-102.

22. Knudsen KA, Tuszynski GP, Huang TF, Niewiarowski S. Trigramin, an RGDcontaining peptide from snake venom, inhibits cell-substratum adhesion of human melanoma cells. Exp Cell Res. 1988;179:42-9. 
23. Sheu JR, Lin CH, Chung JL, Teng CM, Huang TF. Triflavin, an Arg-Gly-Aspcontaining antiplatelet peptide inhibits cell-substratum adhesion and melanoma cell-induced lung colonization. Jpn J Cancer Res. 1992;83:885-93.

24. Yeh $\mathrm{CH}$, Peng HC, Yang RS, Huang TF. Rhodostomin, a snake venom disintegrin, inhibits angiogenesis elicited by basic fibroblast growth factor and suppresses tumor growth by a selective alpha(v)beta(3) blockade of endothelial cells. Mol Pharmacol. 2001;59:1333-42.

25. Yeh $\mathrm{CH}$, Peng HC, Huang TF. Accutin, a new disintegrin, inhibits angiogenesis in vitro and in vivo by acting as integrin alphavbeta3 antagonist and inducing apoptosis. Blood. 1998;92:3268-76.

26. Wu WB, Peng HC, Huang TF. Disintegrin causes proteolysis of beta-catenin and apoptosis of endothelial cells. Involvement of cell-cell and cell-ECM interactions in regulating cell viability. Exp Cell Res. 2003;286:115-27.

27. Zhou Q, Sherwin RP, Parrish C, Richters V, Groshen SG, Tsao-Wei D, et al. Contortrostatin, a dimeric disintegrin from Agkistrodon contortrix contortrix, inhibits breast cancer progression. Breast Cancer Res Treat. 2000;61:249-60.

28. Momic T, Katzehendler J, Benny O, Lahiani A, Cohen G, Noy E, et al. Vimocin and vidapin, cyclic KTS peptides, are dual antagonists of alpha1beta1/ alpha2beta1 integrins with antiangiogenic activity. J Pharmacol Exp Ther. 2014;350:506-19.

29. Eisele G, Wick A, Eisele AC, Clement PM, Tonn J, Tabatabai G, et al. Cilengitide treatment of newly diagnosed glioblastoma patients does not alter patterns of progression. J Neurooncol. 2014;117:141-5.

30. Stupp R, Hegi ME, Gorlia T, Erridge SC, Perry J, Hong YK, et al. Cilengitide combined with standard treatment for patients with newly diagnosed glioblastoma with methylated MGMT promoter (CENTRIC EORTC 2607122072 study): a multicentre, randomised, open-label, phase 3 trial. Lancet Oncol. 2014;15:1100-8.

31. Vansteenkiste J, Barlesi F, Waller CF, Bennouna J, Gridelli C, Goekkurt E, et al. Cilengitide combined with cetuximab and platinum-based chemotherapy as first-line treatment in advanced non-small-cell lung cancer (NSCLC) patients: results of an open-label, randomized, controlled phase II study (CERTO). Ann Oncol. 2015;26:1734-40.

32. Nabors LB, Fink KL, Mikkelsen T, Grujicic D, Tarnawski R, Nam do H, et al. Two cilengitide regimens in combination with standard treatment for patients with newly diagnosed glioblastoma and unmethylated MGMT gene promoter: results of the open-label, controlled, randomized phase II CORE study. Neuro Oncol. 2015;17:708-17.

33. West AP, Koblansky AA, Ghosh S. Recognition and signaling by toll-like receptors. Annu Rev Cell Dev Biol. 2006;22:409-37.

34. Van Amersfoort ES, Van Berkel TJ, Kuiper J. Receptors, mediators, and mechanisms involved in bacterial sepsis and septic shock. Clin Microbiol Rev. 2003;16:379-414.

35. Gerold G, Abu Ajaj K, Bienert M, Laws HJ, Zychlinsky A, de Diego JL. A Toll-like receptor 2-integrin beta3 complex senses bacterial lipopeptides via vitronectin. Nat Immunol. 2008;9:761-8.

36. Hsu CC, Chuang WJ, Chang CH, Tseng YL, Peng HC, Huang TF. Improvements in endotoxemic syndromes using a disintegrin, rhodostomin, through integrin alphavbeta3-dependent pathway. J Thromb Haemost. 2011;9:593-602.

37. Hsu CC, Chuang WJ, Chung $\mathrm{CH}$, Chang CH, Peng HC, Huang TF. Snake venom disintegrin inhibits the activation of toll-like receptors and alleviates sepsis through integrin alphaVbeta3 blockade. Sci Rep. 2016;6:23387.

38. Bassand JP. Current antithrombotic agents for acute coronary syndromes: focus on bleeding risk. Int J Cardiol. 2013;163:5-18.

39. Bougie DW, Rasmussen M, Zhu J, Aster RH. Antibodies causing thrombocytopenia in patients treated with RGD-mimetic platelet inhibitors recognize ligand-specific conformers of alphallb/beta3 integrin. Blood. 2012;119:6317-25.

40. Huang TF, Chang $\mathrm{CH}$, Ho PL, Chung CH. FcgammaRIl mediates platelet aggregation caused by disintegrins and GPIIb/Illa monoclonal antibody, AP2. Exp Hematol. 2008;36:1704-13.

41. Gao C, Boylan B, Bougie D, Gill JC, Birenbaum J, Newman DK, et al. Eptifibatide-induced thrombocytopenia and thrombosis in humans require FcgammaRlla and the integrin beta3 cytoplasmic domain. J Clin Invest. 2009;119:504-11.

42. Blue R, Murcia M, Karan C, Jirouskova M, Coller BS. Application of highthroughput screening to identify a novel alphallb-specific small molecule inhibitor of alphallbbeta3-mediated platelet interaction with fibrinogen. Blood. 2008;111:1248-56
43. Zhu J, Zhu J, Negri A, Provasi D, Filizola M, Coller BS, et al. Closed headpiece of integrin alphallbbeta3 and its complex with an alphallbbeta3-specific antagonist that does not induce opening. Blood. 2010;116:5050-9.

44. Shen B, Zhao X, O'Brien KA, Stojanovic-Terpo A, Delaney MK, Kim K, et al. A directional switch of integrin signalling and a new anti-thrombotic strategy. Nature. 2013;503:131-5.

45. Tadokoro S, Shattil SJ, Eto K, Tai V, Liddington RC, de Pereda JM, et al. Talin binding to integrin beta tails: a final common step in integrin activation. Science. 2003;302:103-6.

46. Vinogradova O, Velyvis A, Velyviene A, Hu B, Haas T, Plow E, et al. A structural mechanism of integrin alpha(llb)beta(3) "inside-out" activation as regulated by its cytoplasmic face. Cell. 2002;110:587-97.

47. Haling JR, Monkley SJ, Critchley DR, Petrich BG. Talin-dependent integrin activation is required for fibrin clot retraction by platelets. Blood. 2011;117: 1719-22.

48. Hsu CC, Chuang WJ, Chung $\mathrm{CH}$, Chang $\mathrm{CH}$, Peng HC, Huang TF. Improved antithrombotic activity and diminished bleeding side effect of a PEGylated alphallbbeta3 antagonist, disintegrin. Thromb Res. 2016;143:3-10.

\section{Submit your next manuscript to BioMed Central and we will help you at every step:}

- We accept pre-submission inquiries

- Our selector tool helps you to find the most relevant journal

- We provide round the clock customer support

- Convenient online submission

- Thorough peer review

- Inclusion in PubMed and all major indexing services

- Maximum visibility for your research

Submit your manuscript at www.biomedcentral.com/submit
) Biomed Central 